\title{
Variability in Sensitivity to Metalaxyl in vitro, Pathogenicity, and Control of Pythium spp. on Sugar Beet
}

\author{
J. R. Brantner, Research Fellow, and Carol E. Windels, Professor, Northwest Experiment Station, University of \\ Minnesota, Crookston 56716
}

\begin{abstract}
Brantner, J. R., and Windels, C. E. 1998. Variability in sensitivity to metalaxyl in vitro, pathogenicity, and control of Pythium spp. on sugar beet. Plant Dis. 82:896-899.

Pythium ultimum var. sporangiiferum (76 isolates) and P. aphanidermatum (21 isolates) cultured from diseased sugar beet seedlings in Minnesota and North Dakota were tested for sensitivity to metalaxyl, pathogenicity on sugar beet, and disease control by metalaxyl seed treatment. Sensitivity to metalaxyl (effective concentration causing $50 \%$ growth inhibition $\left[\mathrm{EC}_{50}\right]$ ) was determined by linear growth on corn meal agar amended with $0,0.01,0.1,1,10$, and $100 \mu \mathrm{g}$ a.i. metalaxyl ml-1 after $48 \mathrm{~h}$ in the dark at $21 \pm 1^{\circ} \mathrm{C}$. Variation among isolates was significant $(P=0.05)$ within and between species, and $\mathrm{EC}_{50}$ values averaged 0.16 (range: 0.05 to $1.30 \mu \mathrm{g}$ $\mathrm{ml}^{-1}$ ) for $P$. ultimum var. sporangiiferum and 2.06 (range: 1.19 to $3.12 \mu \mathrm{g} \mathrm{ml}^{-1}$ ) for $P$. aphanidermatum. In pathogenicity tests on sugar beet, most isolates of $P$. ultimum var. sporangiiferum (72 of 76) and all of $P$. aphanidermatum significantly $(P=0.05)$ decreased final stands compared to the noninoculated control. There was no correlation between aggressiveness in the absence of metalaxyl and in vitro sensitivity to metalaxyl. When Pythium-infested soil was planted with seed treated with metalaxyl at the standard $\left(0.625 \mathrm{~g} \mathrm{ai.}^{-1}\right)$ or half rate, some isolates that were least sensitive to metalaxyl in vitro resulted in a significant $(P=0.05)$ reduction in disease control. These results may explain, at least in part, why producers do not attain expected stands when they plant metalaxyl-treated sugar beet seed.
\end{abstract}

Additional keywords: Beta vulgaris

Sugar beet (Beta vulgaris L.) is susceptible to numerous diseases, including seed rot, preemergence and postemergence damping-off, and root rot (18). In the Red River Valley (RRV) of Minnesota and North Dakota and in west-central Minnesota, Pythium spp. are isolated from dying seedlings, particularly in wet seasons or when fields are poorly drained, soil is compacted, or emergence is delayed. Identification of 37 Pythium isolates from dying seedlings (randomly selected from a collection of over 100) included 28 isolates of $P$. ultimum Trow. var. sporangiiferum Drechs., 7 of $P$. aphanidermatum (Edson) Fitzp., and 1 each of $P$. irregulare Buisman and $P$. acanthicum Drechs. (15). These species (excluding $P$. acanthicum) have been reported on sugar beet (27), but $P$. ultimum and $P$. aphanidermatum are the most common pathogens (18).

Corresponding author: J. R. Brantner

E-mail: jbrantne@mail.crk.umn.edu

This research was supported by the Minnesota Agricultural Experiment Station and by a grant from the Sugar Beet Research and Education Board of Minnesota and North Dakota, Fargo, ND 58105. Contribution No. 971010001 of the Minnesota Agricultural Experiment Station.

Accepted for publication 20 April 1998.

Publication no. D-1998-0526-02R

(C) 1998 The American Phytopathological Society
Sugar beet is very susceptible to Pythium seed rot and damping-off (17). All seed sold to producers in the RRV and west-central Minnesota are pretreated with fungicide and, since 1992, have been treated with metalaxyl (Apron; Novartis, Greensboro, NC) to control Pythium spp. Other seed treatment fungicides are added to control Aphanomyces cochlioides Drechs., Phoma betae (A. B. Frank), and Rhizoctonia solani (Kühn). Metalaxyl (Ridomil; Novartis) also is available as a supplemental in-furrow treatment at planting, but generally is unnecessary and not commonly applied. Viability of commercial seed is between 90 and $95 \%$, yet emergence typically is considerably lower. Emergence of 42 commercial cultivars treated with Apron + Thiram $(0.625+2.5$ g a.i. $\mathrm{kg}^{-1}$ seed, respectively) evaluated at five locations in 1996 averaged $61 \%$, and for individual cultivars ranged from 49 to $71 \%$ (Dave Hilde, American Crystal Sugar Co., personal communication). This rate of emergence is not perceived as a problem when producers plant seed to attain high plant populations and then thin to desired stands. When producers plant directly to desired stand, an increasingly popular practice, reduced emergence results in sparse and uneven stands. Factors contributing to reduced emergence include agronomic practices, environmental conditions, pesticide damage, insects, and diseases. Frequently, the cause of reduced stand in a specific field is impossible to diagnose because the damage occurs before the problem is noticed by the producer.

Metalaxyl is a phenylamide fungicide which inhibits rRNA synthesis of species in the Peronopsorales (9). Variation in sensitivity to metalaxyl has been reported among and within species of Pythium $(7,28)$, Phytophthora $(4,5,8,10,13,25)$, and other related genera (6) and has been associated with reduced disease control $(6,7,19,20)$. Resistance to metalaxyl has been induced in the laboratory with species of Pythium, Phytophthora, and Peronospora $(2,3)$. These reports have raised the question of whether poor sugar beet emergence may be attributed, at least in part, to insensitivity of Pythium spp. to metalaxyl.

This study was conducted to evaluate cultures of $P$. ultimum var. sporangiiferum and $P$. aphanidermatum isolated from diseased sugar beet seedlings for sensitivity to metalaxyl in vitro; to determine if aggressiveness and metalaxyl sensitivity of isolates was related by correlating pathogenicity of these isolates on sugar beet with in vitro metalaxyl sensitivity; and to evaluate the control by metalaxyl seed treatment of isolates with different sensitivities to metalaxyl in vitro. A brief report has been published (1).

\section{MATERIALS AND METHODS}

Pythium isolates. Cultures were isolated from dying sugar beet seedlings collected in 1991 to 1993 from 47 fields in Minnesota and North Dakota (usually within 3 weeks after emergence) or from seedlings grown in the greenhouse in field-collected soil (within 2 weeks after emergence). All isolates were from fields where metalaxyl had never been used or where metalaxyl had been used as a seed treatment for the first time. Seedlings were surface-treated with $0.5 \% \mathrm{NaOCl}$ for $15 \mathrm{~s}$, rinsed twice with sterile distilled water (SDW), and then placed in SDW or on potato dextrose agar (PDA). Tips of hyphae were transferred to PDA; 97 isolates were identified (27) and stored at $-80^{\circ} \mathrm{C}(16)$.

In vitro tests for sensitivity to metalaxyl. Corn meal agar (CMA) at $56^{\circ} \mathrm{C}$ was amended with $0,0.01,0.1,1,10$, and $100 \mu \mathrm{g}$ a.i. metalaxyl $\mathrm{ml}^{-1}$ and dispensed ( $20 \mathrm{ml} / 1.5$ - by $9-\mathrm{cm}$ diameter plastic petri plate). A 6-mm-diameter disk was transferred from the margin of a 3-day-old $P y$ thium culture on CMA to the inside edge of a petri dish containing the medium (4 rep- 
licate plates per medium for each of 97 isolates). Dishes were incubated in the dark at $21 \pm 1{ }^{\circ} \mathrm{C}$ using a randomized block design with time as the blocking factor. After $48 \mathrm{~h}$, linear growth of fungal colonies was measured. The concentration of metalaxyl causing 50\% growth inhibition compared to growth on nonamended CMA $\left(\mathrm{EC}_{50}\right)$ was estimated for each isolate from the fitted regression line of the logit-transformed percent inhibition plotted against log-transformed fungicide concentration (14). The experiment was conducted twice.

Pathogenicity tests. The 97 isolates of Pythium were evaluated for pathogenicity on sugar beet seedlings by an inoculumlayer technique $(12,21)$. Soil mix consisted of field soil, sand, and peat moss $(3: 1: 1$ by volume) that was moistened and autoclaved for $1 \mathrm{~h}$ on each of two consecutive days. Plastic pots (10-cm-diameter) were lined with paper toweling, and $250 \mathrm{~cm}^{3}$ soil was added to each pot. A 3-day-old culture of a Pythium sp. grown on $2 \%$ water agar (WA, 9-cm-diameter) was placed on the soil surface, cut into quarter sections to allow passage of water, and then covered with $50 \mathrm{~cm}^{3}$ soil. Twenty-five Maribo Ultramono sugar beet seeds were equidistantly placed on the soil surface and covered with $50 \mathrm{~cm}^{3}$ soil. Controls included
WA added to soil and soil without WA. Pots were placed in incubators $\left(25 \pm 1^{\circ} \mathrm{C}\right.$, $12 \mathrm{~h}$ photoperiod) in a randomized block design with four replicates (one replicate per incubator). Soil was watered to keep it moist. Stand counts were taken at emergence and then every 3 to 4 days until 3 weeks after planting. The experiment was conducted twice.

To fulfill Koch's postulates, dying seedlings were removed at each stand count, and at least one plant from each pot was assayed to verify presence of the appropriate Pythium sp. Cotyledons were removed and the remainder of the seedling was washed in distilled water, surface-treated in $0.5 \% \mathrm{NaOCl}$ for $15 \mathrm{~s}$, rinsed twice in SDW, and placed in a section of a quad plate containing $5 \mathrm{ml} \mathrm{SDW}$. After 24 to 48 $\mathrm{h}$, seedlings were microscopically examined for structures characteristic of the Pythium species.

Pythium control with metalaxyl seed treatment. Based on rankings from the in vitro screening of Pythium isolates for sensitivity to metalaxyl, 20 isolates were selected to evaluate disease control by seed treatment with metalaxyl. These isolates included the 5 least-sensitive isolates of $P$. aphanidermatum $\left(\mathrm{EC}_{50}\right.$ values from 2.70 to $3.12 \mu \mathrm{g} \mathrm{ml}^{-1}$ ), the 5 least-sensitive isolates
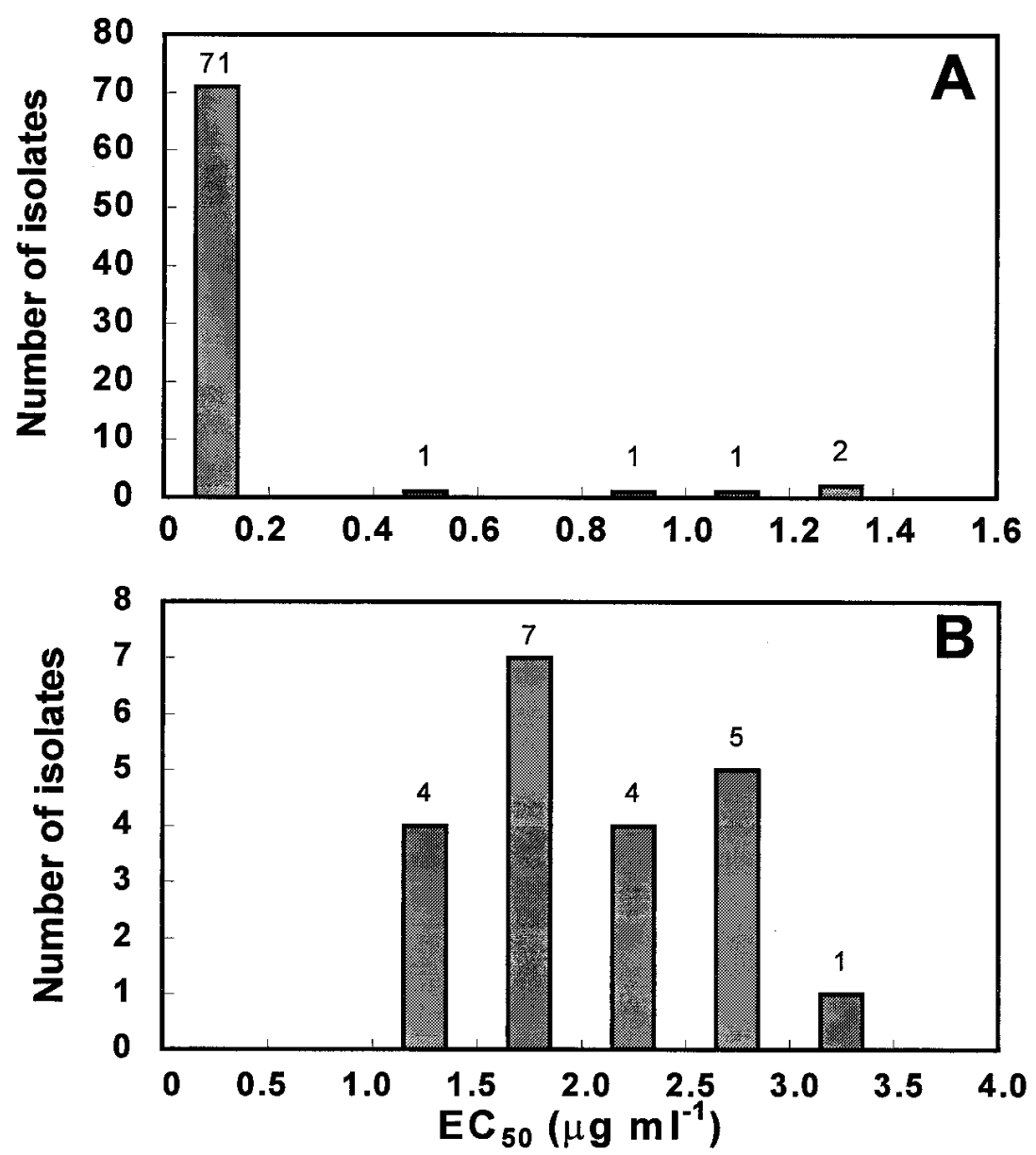

Fig. 1. Distribution of $\mathrm{EC}_{50}$ values (concentration of metalaxyl causing $50 \%$ growth inhibition $48 \mathrm{~h}$ after inoculation of corn meal agar with the fungicide) for (A) 76 isolates of Pythium ultimum var. sporangiiferum and (B) 21 isolates of $P$. aphanidermatum.

of $P$. ultimum var. sporangiiferum $\left(\mathrm{EC}_{50}\right.$ values from 0.60 to $1.30 \mu \mathrm{g} \mathrm{ml}^{-1}$ ), and 10 isolates of $P$. ultimum var. sporangiiferum that were sensitive to metalaxyl $\left(\mathrm{EC}_{50}\right.$ values from 0.05 to $0.10 \mu \mathrm{g} \mathrm{ml}^{-1}$ ). Sugar beet seed of Maribo Ultramono was treated with metalaxyl (Apron 50WP) at 0.625 (standard rate), 0.312 (half the standard rate, used to emphasize differences), and 0 (control) g a.i. $\mathrm{kg}^{-1}$ seed (11). Soil was prepared and individually infested with each of the 20 isolates as previously described. Pots were arranged in a randomized block design (six replicates per treatment) in a greenhouse at $25 \pm 3^{\circ} \mathrm{C}$ and a 12 -h photoperiod for 3 weeks. Stand counts and seedling assays for pathogen verification were done as previously described. The experiment was conducted twice.

Statistical analyses. Data from repeated experiments were combined for analysis. To stabilize variances, $\mathrm{EC}_{50}$ values were adjusted by log transformation and percent final stand values from pathogenicity tests and efficacy tests (with half-standard rate and no metalaxyl seed treatment) were subjected to inverse sine transformations (24). Experiments were analyzed by analysis of variance (SAS Institute, Cary, NC), and mean separations were according to Fisher's least significant difference test, $P=0.05$.

\section{RESULTS}

In vitro tests for sensitivity to metalaxyl. $\mathrm{EC}_{50}$ values for $P$. ultimum var. sporangiiferum averaged 0.16 (range: 0.05 to $1.30 \mu \mathrm{g}$ $\mathrm{ml}^{-1}$ ). Most isolates (71 of 76) had $\mathrm{EC}_{50}$ values $\leq 0.2 \mu \mathrm{g} \mathrm{ml}^{-1} ; 2$ isolates were within $\geq 0.5$ to $1.0 \mu \mathrm{g} \mathrm{ml}^{-1}$; and 3 isolates were within $>1.0$ to $1.4 \mu \mathrm{g} \mathrm{ml}^{-1}$ (Fig. 1A).

$\mathrm{EC}_{50}$ values for $P$. aphanidermatum averaged 2.06 (range: 1.19 to $3.12 \mu \mathrm{g} \mathrm{ml}^{-1}$ ). The distribution of $\mathrm{EC}_{50}$ values for isolates of $P$. aphanidermatum (Fig. 1B) was spread more evenly throughout a higher range than for isolates of $P$. ultimum var. sporangiiferum.

Pathogenicity tests. At 3 weeks after planting, 73 of 76 isolates of P. ultimum var. sporangiiferum resulted in stands that were significantly $(P=0.05)$ lower $(\bar{x}=$ $7 \%$; range 0 to $82 \%$ ) than the noninoculated control ( $\bar{x}=96 \%$; data not shown). Sixty-two isolates resulted in stands of $<10 \%$.

When $P$. aphanidermatum was evaluated for pathogenicity on sugar beet, the 21 isolates resulted in stands that were significantly $(P=0.05)$ lower $(\bar{x}=9 \%$; range 0 to $60 \%)$ than the noninoculated control $(\bar{x}$ $=96 \%) 3$ weeks after planting (data not shown). Stands were $<10 \%$ for 18 of the isolates.

Correlation coefficients for aggressiveness on sugar beet in the absence of metalaxyl (percent final stand values from pathogenicity tests) and in vitro sensitivity to metalaxyl $\left(\mathrm{EC}_{50}\right.$ values) were not significant $(P=0.05)$ for isolates of $P$. ultimum var. sporangiiferum $(r=0.184)$ or $P$. aphanidermatum $(r=-0.029$; data not shown). 
Pythium control with metalaxyl seed treatment. At the standard rate of metalaxyl seed treatment, average final stands were $91 \%$ for isolates of $P$. aphanidermatum and 88 and $94 \%$ for the leastand most-sensitive isolates of $P$. ultimum var. sporangiiferum, respectively (Table 1). Sugar beet stands were significantly $(P=$ 0.05 ) lower for isolates 55, 21, and 10 of $P$. ultimum var. sporangiiferum and isolate 70 of $P$. aphanidermatum compared to the noninoculated control (Table 1); these isolates had $\mathrm{EC}_{50}$ values among the least sensitive to metalaxyl. There were no significant differences $(P=0.05)$ in stand for the other isolates of $P$. ultimum var. sporangiiferum and $P$. aphanidermatum when metalaxyl was applied at the standard rate compared to the noninoculated control. The correlation coefficient between fungicide sensitivity $\left(\mathrm{EC}_{50}\right.$ values) and final stand with the standard metalaxyl seed treatment was significant only for isolates of P. ultimum var. sporangiiferum ( $r=-$ $0.549,13 \mathrm{df}$ ). When seed was not treated with metalaxyl, the 20 isolates resulted in significantly $(P=0.05)$ lower final stands (range 0 to $58 \%$ ) compared to the noninoculated control $(91 \%)$.
At half the standard rate of metalaxyl seed treatment, the average final stand was $83 \%$ for isolates of P. aphanidermatum and 77 and $90 \%$ for the least- and most-sensitive isolates of $P$. ultimum var. sporangiiferum, respectively (Table 1). Isolates 70 , 72,78 , and 79 of $P$. aphanidermatum and isolates 55, 35, 21, 10, and 95 of $P$. ultimum var. sporangiiferum resulted in significantly $(P=0.05)$ lower stands of sugar beet compared to the noninoculated control (Table 1), and all but isolate 95 had $\mathrm{EC}_{50}$ values among the least sensitive to metalaxyl. These isolates were pathogenic to sugar beet $(P=0.05)$ when seed was not treated with metalaxyl, although isolate 35 of $P$. ultimum var. sporangiiferum was less aggressive, resulting in a final stand of $58 \%$. Isolate 51 of $P$. ultimum var. sporangiiferum was the only culture from the 5 least-sensitive isolates of this species that resulted in stands not significantly different from the noninoculated control at the halfrate of metalaxyl seed treatment. This isolate was less aggressive, however, on untreated seed. The correlation coefficient between fungicide sensitivity $\left(\mathrm{EC}_{50}\right.$ values) and final stand with half the standard rate of metalaxyl seed treatment was significant only for isolates of $P$. ultimum var. sporangiiferum $(r=-0.549,13 \mathrm{df})$.

\section{DISCUSSION}

The range of sensitivity to metalaxyl that occurred among isolates of $P$. ultimum var. sporangiiferum $\left(\mathrm{EC}_{50}\right.$ values ranged from 0.05 to $1.30 \mu \mathrm{g} \mathrm{ml}^{-1}$ ) and $P$. aphanidermatum $\left(\mathrm{EC}_{50}\right.$ values ranged from 1.19 to $3.12 \mu \mathrm{g} \mathrm{ml}^{-1}$ ) from sugar beet seedlings is consistent with those reported for $P y$ thium species $(7,28)$ and for species and varieties of Phytophthora $(4,5,8,13,22)$. Cook and Zhang (7) reported a narrow range of sensitivity to metalaxyl of $P$. ultimum var. sporangiiferum pathogenic to wheat $\left(\mathrm{EC}_{50}\right.$ values were estimated as $\leq 0.3 \mathrm{ppm}$ ), but tested only a few isolates. White et al. (28) found an isolate of $P$. aphanidermatum from carrot that had a low $\mathrm{EC}_{50}$ value $\left(0.39 \mu \mathrm{g} \mathrm{ml}^{-1}\right)$ compared to our isolates of this species. Sanders (20), on the other hand, reported that 60 to $75 \%$ of $P$. aphanidermatum isolates from turf grass grew without inhibition on a medium containing 50 and $100 \mathrm{ppm}$ metalaxyl, but these isolates were from a site where metalaxyl had been applied for 3 years.

Table 1. Percent final stand 3 weeks after planting sugar beet seed treated with $0.625,0.312$, and (control) $0 \mathrm{~g}$ a.i. $\mathrm{kg}^{-1}$ seed metalaxyl (Apron 50WP) into soil infested with 1 of 5 isolates of Pythium aphanidermatum or 1 of 15 isolates of P. ultimum var. sporangiiferum that represent different levels of sensitivity to metalaxyl (5 least-sensitive and 10 sensitive based on in vitro $\mathrm{EC}_{50}{ }^{\mathrm{a}}$ values)

\begin{tabular}{|c|c|c|c|c|}
\hline \multirow[b]{2}{*}{ Isolate } & \multirow[b]{2}{*}{$\mathrm{EC}_{50} \mu \mathrm{g} \mathrm{ml}^{-1}\left(\log \mathrm{EC}_{50}\right)^{\mathrm{c}}$} & \multicolumn{3}{|c|}{ Final stand $(\%)^{b}$} \\
\hline & & $0.625 \mathrm{~g} \mathrm{~kg}^{-1 \mathrm{~d}}$ & $0.312 \mathrm{~g} \mathrm{~kg}^{-1 \mathrm{~d}}\left(\sin ^{-1}\right)^{\mathrm{e}}$ & Control $\left(\sin ^{-1}\right)^{\mathrm{e}}$ \\
\hline \multicolumn{5}{|c|}{ P. aphanidermatum } \\
\hline 71 & $3.12(2.41)$ & 91 & $90(1.16)$ & $13(0.13)$ \\
\hline 70 & $2.85(2.44)$ & 89 & $78(0.90)$ & $5(0.05)$ \\
\hline 78 & $2.76(2.40)$ & 91 & $79(0.94)$ & $11(0.11)$ \\
\hline 72 & $2.73(2.43)$ & 94 & $88(1.09)$ & $3(0.03)$ \\
\hline 79 & $2.70(2.40)$ & 90 & $82(0.97)$ & $5(0.05)$ \\
\hline $\bar{x}$ & 2.83 & 91 & 83 & 7 \\
\hline \multicolumn{5}{|c|}{ P. ultimum var. sporangiiferum } \\
\hline \multicolumn{5}{|c|}{ Least sensitive isolates } \\
\hline 51 & $1.30(2.08)$ & 95 & $95(1.34)$ & $42(0.47)$ \\
\hline 55 & $1.21(2.04)$ & 80 & $65(0.72)$ & $2(0.02)$ \\
\hline 35 & $1.03(1.99)$ & 92 & $81(0.98)$ & $58(0.63)$ \\
\hline 21 & $0.86(1.87)$ & 85 & $72(0.82)$ & $3(0.03)$ \\
\hline 10 & $0.60(1.76)$ & 88 & $74(0.84)$ & $4(0.04)$ \\
\hline $\bar{x}$ & 1.00 & 88 & 77 & 22 \\
\hline \multicolumn{5}{|l|}{ Sensitive isolates } \\
\hline 50 & $0.10(0.97)$ & 94 & $91(1.22)$ & $0(0.00)$ \\
\hline 45 & $0.10(0.94)$ & 92 & $90(1.16)$ & $0(0.00)$ \\
\hline 6 & $0.10(0.96)$ & 97 & $93(1.24)$ & $2(0.02)$ \\
\hline 95 & $0.10(0.94)$ & 94 & $79(0.94)$ & $1(0.01)$ \\
\hline 8 & $0.10(0.96)$ & 92 & $91(1.24)$ & $2(0.02)$ \\
\hline 34 & $0.07(0.75)$ & 96 & $94(1.31)$ & $1(0.01)$ \\
\hline 11 & $0.06(0.70)$ & 91 & $88(1.16)$ & $2(0.02)$ \\
\hline 9 & $0.05(0.65)$ & 92 & 89 (1.17) & $3(0.03)$ \\
\hline 27 & $0.05(0.64)$ & 94 & $96(1.35)$ & $1(0.01)$ \\
\hline 38 & $0.05(0.66)$ & 94 & $90(1.15)$ & $9(0.10)$ \\
\hline $\bar{x}$ & 0.08 & 94 & 90 & 2 \\
\hline Noninoculated & & 94 & $95(1.31)$ & $91(1.18)$ \\
\hline Standard error & $(0.22)$ & 6 & $(0.21)$ & $(0.13)$ \\
\hline $\operatorname{LSD},(P=0.05)^{\mathrm{f}}$ & $(0.21)$ & 5 & $(0.17)$ & $(0.10)$ \\
\hline
\end{tabular}

${ }^{\mathrm{a}} \mathrm{EC}_{50}$ is the concentration of fungicide causing $50 \%$ growth inhibition $48 \mathrm{~h}$ after inoculation of corn meal agar amended with metalaxyl. Each value is an average of eight replicates combined from two experiments.

${ }^{\mathrm{b}}$ Each value is an average of 12 replicates combined from two experiments ( 25 seeds planted per replicate).

${ }^{\mathrm{c}}$ Log transformation value.

${ }^{\mathrm{d}}$ Rate of metalaxyl.

${ }^{\mathrm{e}}$ Inverse sine transformation value.

${ }^{\mathrm{f}} \mathrm{LSD}=$ least significant difference. 
Isolates of the two Pythium spp. collected from sugar beet seedlings varied significantly in sensitivity to metalaxyl within and between species. Yet, these isolates were from fields where metalaxyl had not been applied or where metalaxyl had been used as a seed treatment for the first time. A wide range of innate variation among isolates of Pythium, even in fields with no prior history of metalaxyl use, has been reported previously (7). White et al. (28) noted variability in sensitivity to metalaxyl among isolates of Pythium spp. from carrots, and this variability was not related to previous use of metalaxyl.

Based on the evidence in this study, the relationship is unclear between in vitro metalaxyl sensitivity and aggressiveness on sugar beet (an important component of pathogen fitness that influences the risk of developing fungicide resistance in a pathogen population, 23). There was no significant correlation between in vitro metalaxyl sensitivity of all isolates of $P$. ultimum var. sporangiiferum or $P$. aphanidermatum and their aggressiveness on untreated sugar beet. In efficacy tests of select isolates, however, 2 of the 5 least-sensitive isolates of $P$. ultimum var. sporangiiferum were less aggressive in the presence and absence of metalaxyl seed treatment compared to most isolates (Table 1). Also, for the subsample of isolates of $P$. ultimum var. sporangiiferum that were the least and most sensitive to metalaxyl in vitro, the correlation between fungicide sensitivity and aggressiveness on sugar beet with no metalaxyl seed treatment was significant $(P=0.05)$.

The shape of the frequency distributions of $\mathrm{EC}_{50}$ values for P. ultimum var. sporangiiferum and $P$. aphanidermatum, along with results from the tests of control with metalaxyl seed treatment, indicate that biologically meaningful levels of metalaxyl sensitivity are different for the two species. For isolates of P. ultimum var. sporangiiferum, $\mathrm{EC}_{50}$ values were unevenly distributed, with most isolates being very sensitive and a few isolates being much less sensitive (Fig. 1A). Isolates of $P$. aphanidermatum had higher $\mathrm{EC}_{50}$ values but were more evenly distributed (Fig. 1B). The in vitro $\mathrm{EC}_{50}$ values of $P$. ultimum var. sporangiiferum isolates were a better indicator of in vivo disease control with metalaxyl than those of $P$. aphanidermatum. When sugar beet seed treated with the standard rate of metalaxyl were sown into soil infested with $P$. ultimum var. sporangiiferum, final stands were negatively correlated with $\mathrm{EC}_{50}$ values, and 3 isolates of $P$. ultimum var. sporangiiferum that were least sensitive to metalaxyl resulted in significant stand reductions from the noninoculated control. Although the 5 isolates of $P$. aphanidermatum tested for control by metalaxyl seed treatment had the highest $\mathrm{EC}_{50}$ values, only 1 resulted in significant stand reductions from the noninoculated control at the standard rate. In evaluations with half the standard rate of metalaxyl seed treatment, nearly all of the sensitive isolates of $P$. ultimum var. sporangiiferum (based on $\mathrm{EC}_{50}$ values) were controlled, whereas many of the least-sensitive isolates of $P$. ultimum var. sporangiiferum and $P$. aphanidermatum were not controlled at the same level. Similarly, Shew (22) found that in vitro responses corresponded to in vivo responses to metalaxyl in isolates of Phytophthora parasitica var. nicotianae. Variation in sensitivity to metalaxyl may explain, at least in part, why emergence of sugar beet seedlings often is lower than germination of seed. Other factors include variation in amount of fungicide on seed because of differences in seed size and application method (slurry, various coating materials), other pathogens, and soil temperature and moisture.

Although some isolates of Pythium are less sensitive to metalaxyl than others, and this factor may account for some reduction in seedling stands, the continued use of this fungicide as a seed treatment poses limited selection pressure for metalaxyl-resistant isolates (26). Only a small amount of fungicide is applied to seed; it persists in soil for a short time; and only a small proportion of the Pythium population in soil is exposed to metalaxyl. In addition, sugar beet crops are grown on a minimum of a 3year rotation, frequently after crops where metalaxyl is not applied as a seed or soil treatment. If soil application of metalaxyl is used in addition to seed treatment to produce sugar beet and other rotational crops, however, the risk of selecting for naturally occurring strains with less sensitivity will increase, which may result in reduced disease control.

\section{ACKNOWLEDGMENTS}

We thank R. Kuznia for identification of Pythium isolates; J. Nielsen, N. Ellingson, T. Kreutzberg, and D. Schindler for technical assistance; and F. Martin for advice on statistical analyses.

\section{LITERATURE CITED}

1. Brantner, J. R., and Windels, C. E. 1996. Variability in metalaxyl sensitivity of Pythium spp. pathogenic to sugar beet. (Abstr.) Phytopathology 86:520.

2. Bruin, G. C. A., and Edgington, L. V. 1981. Adaptive resistance in Peronosporales to metalaxyl. Can. J. Plant Pathol. 3:201-206.

3. Bruin, G. C. A., and Edgington, L. V. 1982. Induction of fungal resistance to metalaxyl by ultraviolet irradiation. Phytopathology 72:476480.

4. Coffey, M. D., and Bower, L. A. 1984. In vitro variability among isolates of six Phytophthora species in response to metalaxyl. Phytopathology 74:502-506.

5. Coffey, M. D., Klure, L. J., and Bower, L. A. 1984. Variability in sensitivity to metalaxyl of isolates of Phytophthora cinnamomi and Phytophthora citricola. Phytopathology 74:417-422.

6. Cohen, Y., and Coffey, M. D. 1986. Systemic fungicides and the control of Oomycetes. Annu. Rev. Phytopathol. 24:311-338.

7. Cook, R. J., and Zhang, B.-X. 1985. Degrees of sensitivity to metalaxyl within the Pythium spp. pathogenic to wheat in the Pacific Northwest. Plant Dis. 69:686-688.

8. Csinos, A. S., and Bertrand, P. F. 1994. Distribution of Phytophthora parasitica var. nicotianae races and their sensitivity to metalaxyl in Georgia. Plant Dis. 78:471-474.

9. Davidse, L. C. 1988. Phenylamide fungicides: mechanism of action and resistance. Pages 6365 in: Fungicide Resistance in North America. C. J. Delp, ed. APS Press, St. Paul, MN.

10. Goodwin, S. B., and McGrath, M. T. 1995. Insensitivity to metalaxyl among isolates of Phytophthora erythroseptica causing pink rot of potato in New York. Plant Dis. 79:967.

11. Hansing, E. D. 1978. Seed treatments. Pages 88-92 in: Methods for Evaluating Plant Fungicides, Nematicides, and Bactericides. E. I Zehr et al., eds. APS Press, St. Paul, MN.

12. Herr, L. J., and Roberts, D. L. 1980. Characterization of Rhizoctonia populations obtained from sugarbeet fields with differing soil textures. Phytopathology 70:476-480.

13. Hunger, R. M., Hamm, P. B., Horner, C. E., and Hansen, E. M. 1982. Tolerance of Phytophthora megasperma isolates to metalaxyl. Plant Dis. 66:645-649.

14. King-Watson, E. D. 1988. Sensitivity monitoring methods for phenylamide fungicides. Pages 6162 in: Fungicide Resistance in North America. C. J. Delp, ed. APS Press, St. Paul, MN.

15. Kuznia, R., and Windels, C. E. 1993. Identification and pathogenicity of Pythium species isolated from sugarbeet. 1992 Sugarbeet Res. Ext. Rep. 23:153-159.

16. Kuznia, R., and Windels, C. E. 1994. Preservation of Pythium species and Rhizoctonia solani at -80 C. (Abstr.) Phytopathology 84:1149.

17. Kuznia, R. A., Windels, C. E., and Stanghellini, M. E. 1992. Pathogenicity of Pythium species on sugar beet using a thermogradient plate. (Abstr.) Phytopathology 82:1088.

18. Leach, L. D. 1986. Seedling diseases. Pages 4-8 in: Compendium of Beet Diseases and Insects. E. D. Whitney and J. E. Duffus, eds. APS Press, St. Paul, MN.

19. Morton, H. V., and Urech, P. A. 1988. History of the development of resistance to phenylamide fungicides. Pages 59-60 in: Fungicide Resistance in North America. C. J. Delp, ed. APS Press, St. Paul, MN

20. Sanders, P. L. 1984. Failure of metalaxyl to control Pythium blight on turfgrass in Pennsylvania. Plant Dis. 68:776-777.

21. Schmitthenner, A. F., and Hilty, J. W. 1962. A method for studying postemergence seedling root rot. Phytopathology 52:177-179.

22. Shew, H. D. 1985. Response of Phytophthora parasitica var. nicotianae to metalaxyl exposure. Plant Dis. 69:559-562.

23. Staub, T., and Sozzi, D. 1984. Fungicide resistance: a continuing challenge. Plant Dis. 68:1026-1031.

24. Steele, R. G. D., and Torrie, J. H. 1980. Principles and Procedures of Statistics. 2nd ed. McGraw-Hill Book Co., New York.

25. Sujkowski, L. S., Fry, B. A., Power, R. J., Goodwin, S. B., Peever, T. L., Hamlen, R. A., and Fry, W. E. 1995. Sensitivities of Mexican isolates of Phytophthora infestans to chlorothalonil, cymoxanil, and metalaxyl. Plant Dis. 79:1117-1120.

26. Urech, P. A. 1988. Phenylamide resistance management strategies. Pages 74-75 in: Fungicide Resistance in North America. C. J. Delp, ed. APS Press, St. Paul, MN.

27. Van der Plaats-Niterink, A. J. 1981. Monograph of the Genus Pythium. Studies in Mycology 21. Centraalbureau voor Schimmelcultures, Baarn, The Netherlands.

28. White, J. G., Stanghellini, M. E., and Ayoubi, L. M. 1988. Variation in the sensitivity to metalaxyl of Pythium spp. isolated from carrot and other sources. Ann. Appl. Biol. 113:269-277. 